\title{
Effect of Some Preservative Solutions on Some Morphometric Features of Planiliza abu (Heckel, 1843)
}

\author{
Mohammed Inad Ghazwan (ail 1 \\ ${ }^{1}$ Iraqi Natural History Museum and research Center / University of Baghdad \\ Corresponding Author: muhammadinad@yahoo.com
}

\begin{abstract}
Article history:
Received 1 April 2021

Accepted 1 June 2021

keyword: Biometry,

Brackish water,

Expansion and

contraction, External

appearance.

Abstract

The present study attempts to find out the effect of some fish preservatives in the laboratory, such as alcohol and dilute formalin, on some biological characteristics related to the body measurements of those fish preserved in these materials. The fish used in this study were the local Planiliza abu. The processes of expansion and contraction of the bodies of fish preserved in diluted formalin solution at a concentration of $10 \%$ and diluted ethyl alcohol solution at a concentration of $70 \%$. As that the standard length of the specimens of this study, which are separately preserved in formalin $10 \%$ and alcohol $70 \%$, in a completely isolated are fluctuating in change. Constant shrinkage in head length in both diluted formalin and alcohol. Most fish bodies preserved in formalin at a concentration of $10 \%$ gain significant weight gain, in contrast to alcohol preservation.
\end{abstract}

Doi: $10.52951 /$ dasj.21130201

\section{Introduction}

Planiliza abu is one of the Iraqi local fish that belongs to the Mugilidae family. Its total length is $26 \mathrm{~cm}$ and distributed in the Tigris and Euphrates basins; it does not enter the Arab Gulf. It is found in large quantities in all water bodies in the middle and Southern Iraq. Its small size reduces its economic value; nevertheless, it is a popular and local fish with wide popularity in Iraqi markets. This species is also found in the Euphrates River Basin in Syria (Misra, 1947; Khalaf, 1961; Mahdi, 1962; Al-Daham, 1984). What distinguishes this species of this family is their bright silver color and tapering bodies (Razzaq et al, 2015). It is considered one of the coastal tropical fish that live in a salty and little salty environment as shown by (Thomson, 1997; Nelson, 2006). The most important methods for preserving fishes, in general, are four internationally known methods, which are freezing, preservation in salt, preservation with chemicals represented by diluted formalin and ethyl alcohol. These preservatives may affect some of the biometrics of fish specimens, especially of different lengths (Jawad, 2003). Many standard changes appear on the fish bodies preserved in formalin and alcohol for different standard periods. Evidence come from many researchers as indicated by (Lux, 1960; Parker,1963; Stobo,1972; Engel, 1974; Sayers, 1987 and Haubroc et al,2018). These substances may cause contractions and shrinkage in the bodies of the fish preserved in them (Billy, 1982; Al-Hassan and Abdullah, 1992; Al-Hassan and Shawafi, 1997; Al-Hassan et al, 1999, 2000).

Some researchers argue that there is a loss in the weight of the specimens preserved in formalin, (Cultter and Whitesel, 1956; Parker, 1963). Billy (1982) says that there is a loss in weight and there is a clear difference between the live weight and the weight of the fish after preserving in both solutions: diluted formalin and alcohol (Banha et al, 2017).

Kelvin 1994 believes that it is possible that the concentrations of some elements, especially heavy elements in fish bodies preserved in formalin, may change over time due to formalin acidity and the interaction of these elements over time. Formalin acidity and the interaction lead to an increase in the concentrations of some of them or a decrease in the concentrations of others, or they even lead to the disappearance of these elements due to the variable interactions caused by the long period of preservation in formalin. The elements also vary in their concentrations over time if the fish specimens are preserved with dilute alcohol to a concentration of $70-75 \%$. The effect of these two solutions, formalin, and alcohol, is clear during the first periods of preservation with the disappearance of fish color if the species have clear coloration 
(Dallinger et al, 1987). In this study, we find that these elements are concentrated in the bodies of the fish at a higher rate than those in the water, in their surroundings, or other sediments in this environment, as a result of consuming the organisms in that environment (Olaifa et al, 2004). On the other hand, the presence of these heavy elements in different concentrations in the bodies of fish is a sign of the pollution occurring in the environment of these fish (Jassem et al, 2007). The bodies of fish may be preserved in formalin $10 \%$ and then stored in alcohol $70 \%$. Great changes in the bodies of fish, preserved according to this method and for a long time in several forms, will appear as indicated by (Wilke et al. 1996; Arrington and Winemille, 2002).

\section{Materials and Methods}

\section{Ethical Approval}

All applicable national and international guidelines for the care and use of animals were followed.

\section{Experimental Animal}

A total of $40 \mathrm{P}$. abu fish were divided into two groups, each group consisted of 20 fish. The first group was kept in a diluted formalin solution at a concentration of $10 \%$; the second group was kept in a diluted ethyl alcohol solution at a concentration of $70 \%$. The two solutions were diluted with non-ionic distilled water. Some biometrics was measured by using the traditional method to calculate the total, standard length, head length, and weight for both groups. The readings were recorded once a week for an entire month.

\section{Results and Discussion}

Figure 1 the local P. abu fish. The general shape and outward appearance of the fish used in this study.

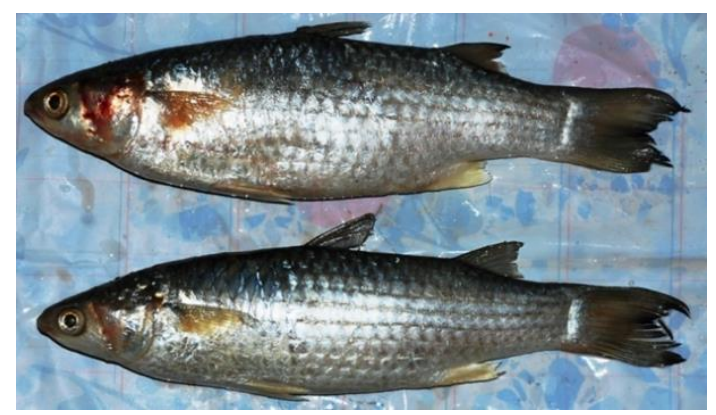

Figure 1. Planiliza abu

The biometric rates of $\mathrm{P}$. abu fish preserved in alcohol were $70 \%$ in the four weeks: $20.18 \mathrm{~cm}$ was the total length, the standard length was $16.5 \mathrm{~cm}$, the head length was $4 \mathrm{~cm}$ and the weight was $22.8 \mathrm{~g}$. However, the biometric rates for fish preserved in formalin were $10 \%$ for the four weeks: the total length was $19.6 \mathrm{~cm}$, standard length was $16.4 \mathrm{~cm}$, the head length was $4 \mathrm{~cm}$ and the weight was $19.8 \mathrm{~g}$. From table 1 we can follow up general linear model between-subjects factors. Then it follows with table 2 the descriptive statistics. Table 3 indicates the analysis of variance of specimens preservative and time in general in addition to the interaction between them.

Table 1. general linear model between-subjects factors

\begin{tabular}{|c|c|c|c|}
\hline \multicolumn{2}{|c|}{} & Value Label & N \\
\hline \multirow{2}{*}{ Preservative_Type } & 1 & Alcohol 70\% & 80 \\
\cline { 2 - 4 } & 2 & Formalin 10\% & 80 \\
\hline \multirow{3}{*}{ Time } & 1 & 1st Week & 40 \\
\cline { 2 - 4 } & 2 & 2nd Week & 40 \\
\cline { 2 - 4 } & 3 & 3rd Week & 40 \\
\cline { 2 - 4 } & 4 & 4th Week & 40 \\
\hline
\end{tabular}

Table 2. the descriptive statistics of the experiment

\begin{tabular}{|c|c|c|c|c|c|}
\hline & Preservative_Type & Time & Mean & Std. Deviation & $\mathbf{N}$ \\
\hline \multirow{13}{*}{ Total_Length $(\mathrm{cm})$} & \multirow{5}{*}{ Alcohol $70 \%$} & 1st Week & 10.325 & .4128 & 20 \\
\hline & & 2nd Week & 10.255 & .4524 & 20 \\
\hline & & 3rd Week & 10.420 & .3901 & 20 \\
\hline & & 4th Week & 10.370 & .4402 & 20 \\
\hline & & Total & 10.342 & .4209 & 80 \\
\hline & \multirow{5}{*}{ Formalin $10 \%$} & 1st Week & 9.665 & .4258 & 20 \\
\hline & & 2nd Week & 9.980 & .4538 & 20 \\
\hline & & 3rd Week & 9.920 & .4503 & 20 \\
\hline & & 4th Week & 9.710 & .4340 & 20 \\
\hline & & Total & 9.819 & .4531 & 80 \\
\hline & \multirow{3}{*}{ Total } & 1st Week & 9.995 & .5320 & 40 \\
\hline & & 2nd Week & 10.118 & .4684 & 40 \\
\hline & & 3rd Week & 10.170 & .4869 & 40 \\
\hline
\end{tabular}




\begin{tabular}{|c|c|c|c|c|c|}
\hline & & 4th Week & 10.040 & .5458 & 40 \\
\hline & & Total & 10.081 & .5090 & 160 \\
\hline & & 1 st Week & 8.280 & .3302 & 20 \\
\hline & & 2nd Week & 8.415 & .3588 & 20 \\
\hline & Alcohol 70\% & 3rd Week & 8.545 & .3410 & 20 \\
\hline & & 4th Week & 8.310 & .3684 & 20 \\
\hline & & Total & 8.388 & .3588 & 80 \\
\hline & & 1st Week & 8.120 & .3901 & 20 \\
\hline & & 2nd Week & 8.340 & .3169 & 20 \\
\hline Standard_Length $(\mathrm{cm})$ & Formalin $10 \%$ & 3rd Week & 8.225 & .4339 & 20 \\
\hline & & 4th Week & 8.150 & .3763 & 20 \\
\hline & & Total & 8.209 & .3839 & 80 \\
\hline & & 1st Week & 8.200 & .3658 & 40 \\
\hline & & 2nd Week & 8.377 & .3363 & 40 \\
\hline & Total & 3rd Week & 8.385 & .4179 & 40 \\
\hline & & 4th Week & 8.230 & .3764 & 40 \\
\hline & & Total & 8.298 & .3811 & 160 \\
\hline & & 1st Week & 2.070 & .1689 & 20 \\
\hline & & 2nd Week & 2.060 & .0883 & 20 \\
\hline & Alcohol 70\% & 3rd Week & 2.080 & .0894 & 20 \\
\hline & & 4th Week & 2.050 & .1539 & 20 \\
\hline & & Total & 2.065 & .1284 & 80 \\
\hline & & 1st Week & 1.930 & .2296 & 20 \\
\hline & & 2nd Week & 2.075 & .0444 & 20 \\
\hline Head_Length $(\mathrm{cm})$ & Formalin $10 \%$ & 3rd Week & 1.985 & .0366 & 20 \\
\hline & & 4th Week & 1.910 & .2174 & 20 \\
\hline & & Total & 1.975 & .1703 & 80 \\
\hline & & 1st Week & 2.000 & .2112 & 40 \\
\hline & & 2nd Week & 2.068 & .0694 & 40 \\
\hline & Total & 3rd Week & 2.032 & .0829 & 40 \\
\hline & & 4th Week & 1.980 & .1990 & 40 \\
\hline & & Total & 2.020 & .1569 & 160 \\
\hline & & 1st Week & 13.950 & 1.2763 & 20 \\
\hline & & 2nd Week & 11.650 & 1.2258 & 20 \\
\hline & Alcohol 70\% & 3rd Week & 11.950 & 1.3945 & 20 \\
\hline & & 4th Week & 14.000 & 1.3765 & 20 \\
\hline & & Total & 12.888 & 1.6988 & 80 \\
\hline & & 1st Week & 10.950 & 1.6376 & 20 \\
\hline & & 2nd Week & 10.100 & 1.7741 & 20 \\
\hline Weight (gm) & Formalin $10 \%$ & 3rd Week & 10.950 & 1.5720 & 20 \\
\hline & & 4th Week & 10.900 & 1.7442 & 20 \\
\hline & & Total & 10.725 & 1.6912 & 80 \\
\hline & & 1st Week & 12.450 & 2.0995 & 40 \\
\hline & & 2nd Week & 10.875 & 1.6975 & 40 \\
\hline & Total & 3rd Week & 11.450 & 1.5517 & 40 \\
\hline & & 4th Week & 12.450 & 2.2066 & 40 \\
\hline & & Total & 11.806 & 2.0078 & 160 \\
\hline
\end{tabular}


Diyala Agricultural Sciences Journal Vol (13) No 2, 2021: 1-9

Table 3. Analysis of variance of specimens preservative and time in general in addition to the interaction between them

\begin{tabular}{|c|c|c|c|c|c|c|}
\hline Source & Dependent Variable & $\begin{array}{c}\text { Type III Sum of } \\
\text { Squares }\end{array}$ & df & Mean Square & $\mathbf{F}$ & Sig. \\
\hline \multirow{4}{*}{ Corrected Model } & Total_Length & $12.701^{\mathrm{a}}$ & 7 & 1.814 & 9.681 & .000 \\
\hline & Standard_Length & $2.717^{\mathrm{b}}$ & 7 & .388 & 2.896 & .007 \\
\hline & Head_Length & $.661^{\mathrm{c}}$ & 7 & .094 & 4.410 & .000 \\
\hline & Weight & $293.044^{\mathrm{d}}$ & 7 & 41.863 & 18.288 & .000 \\
\hline \multirow{4}{*}{ Intercept } & Total_Length & 16259.040 & 1 & 16259.040 & 86749.885 & .000 \\
\hline & Standard_Length & 11017.421 & 1 & 11017.421 & 82201.395 & .000 \\
\hline & Head_Length & 652.864 & 1 & 652.864 & 30487.044 & .000 \\
\hline & Weight & 22302.006 & 1 & 22302.006 & 9742.506 & .000 \\
\hline \multirow{4}{*}{ Preservative_Type } & Total_Length & 10.973 & 1 & 10.973 & 58.544 & .000 \\
\hline & Standard_Length & 1.278 & 1 & 1.278 & 9.536 & .002 \\
\hline & Head_Length & .324 & 1 & .324 & 15.130 & .000 \\
\hline & Weight & 187.056 & 1 & 187.056 & 81.714 & .000 \\
\hline \multirow{4}{*}{ Time } & Total_Length & .733 & 3 & .244 & 1.304 & .275 \\
\hline & Standard_Length & 1.125 & 3 & .375 & 2.797 & .042 \\
\hline & Head_Length & .177 & 3 & .059 & 2.747 & .045 \\
\hline & Weight & 72.919 & 3 & 24.306 & 10.618 & .000 \\
\hline \multirow{4}{*}{$\begin{array}{c}\text { Preservative_Type } \\
* \text { Time }\end{array}$} & Total_Length & .996 & 3 & .332 & 1.771 & .155 \\
\hline & Standard_Length & .314 & 3 & .105 & .781 & .506 \\
\hline & Head_Length & .161 & 3 & .054 & 2.498 & .062 \\
\hline & Weight & 33.069 & 3 & 11.023 & 4.815 & .003 \\
\hline \multirow{4}{*}{ Error } & Total_Length & 28.489 & 152 & .187 & & \\
\hline & Standard_Length & 20.372 & 152 & .134 & & \\
\hline & Head_Length & 3.255 & 152 & .021 & & \\
\hline & Weight & 347.950 & 152 & 2.289 & & \\
\hline \multirow{4}{*}{ Total } & Total_Length & 16300.230 & 160 & & & \\
\hline & Standard_Length & 11040.510 & 160 & & & \\
\hline & Head_Length & 656.780 & 160 & & & \\
\hline & Weight & 22943.000 & 160 & & & \\
\hline \multirow{4}{*}{ Corrected Total } & Total_Length & 41.190 & 159 & & & \\
\hline & Standard_Length & 23.089 & 159 & & & \\
\hline & Head_Length & 3.916 & 159 & & & \\
\hline & Weight & 640.994 & 159 & & & \\
\hline \multicolumn{7}{|c|}{ a. R Squared $=.308($ Adjusted R Squared $=.277)$} \\
\hline \multicolumn{7}{|c|}{ b. R Squared $=.118($ Adjusted R Squared $=.077)$} \\
\hline \multicolumn{7}{|c|}{ c. R Squared $=.169($ Adjusted R Squared $=.131)$} \\
\hline \multicolumn{7}{|c|}{ d. R Squared $=.457$ (Adjusted R Squared $=.432$ ) } \\
\hline
\end{tabular}


Table 4 shows total length of $\mathrm{P}$. abu fish bodies preserved in formalin at the first week began to increase and the expansion occurred in the bodies in the second week. Then the body began to shrink down through the last week of the experiment and the total length regain its initial measurement when first to stored in the dilute formalin solution. We notice, from the same table, that the total length of the fish preserved in diluted alcohol start to decline and the shrinkage of the bodies occurred at the second week. The total length increased and the expansion was at its peak at the third week of the experiment to settle at a total length higher than the initial total length of the fish bodies at the start of the experiment. This indicates the expansion and contraction processes in the fish bodies preserved in these two solutions, which is confirmed by (Jawad, 2003). Most of the biometrics Fish bodies preserved in formalin at a concentration of $5 \%$ were stable until the experiment was in the seventh week when changes appeared in these measurements; noting that the formalin concentration was not the same in the two experiments. (Shields and Carlson, 1996) explained that the bodies of salmon fish preserved in alcohol had a loss in total length at day 16 of the experiment; it stabilize on day 70 of the same experiment; the total length of the salmon's bodies increased after this period. The results were identical to the present study when there is shrinkage in the bodies of fish, noting that the two types are different in these two studies. (Shields and Carlson, 1996) studied the bodies of salmon larvae whereas this study included adult P. abu fish. No significant effect was detected in the salmon fish bodies preserved in formalin 5\% distilled water. All the studied biometrics appeared to be rather stable as shown by (Shields and Carlson, 1996), but in our study, there was a clear change in most of P. abu studied biological characteristics. It may be attributed to the difference between formalin concentrations in the two experiments, or to the type of water in which these solutions were diluted. (Razzaq et al, 2015) also confirms that there was an increase in the total length of fish preserved in a formalin solution at a concentration of $10 \%$, the length of the experiment, especially in the first days of collecting samples, and this is what happened in this study when there was an increase in the total length of fish preserved for two weeks of experience
Table 4. Total length

\begin{tabular}{|c|c|c|c|}
\hline \multirow{2}{*}{ Time } & \multirow{2}{*}{$\mathrm{N}$} & \multicolumn{2}{|c|}{ Subset for alpha $=0.05$} \\
\cline { 3 - 4 } & & 1 & 2 \\
\hline 1st Week & 20 & 9.665 & \\
\hline 4th Week & 20 & 9.710 & 9.710 \\
\hline 3rd Week & 20 & 9.920 & 9.920 \\
\hline 2nd Week & 20 & & 9.980 \\
\hline Sig. & & .088 & .070 \\
\hline
\end{tabular}

Means for groups in homogeneous subsets are displayed.

a. Preservative_Type $=$ Formalin $10 \%$

b. Uses Harmonic Mean Sample Size $=20.000$.

Table 5. Standard length

\begin{tabular}{|c|c|c|c|}
\hline \multirow{2}{*}{ Time } & \multirow{2}{*}{$\mathrm{N}$} & \multicolumn{2}{|c|}{ Subset } \\
\cline { 3 - 4 } & & 1 & 2 \\
\hline 1st Week & 40 & 8.200 & \\
\hline 4th Week & 40 & 8.230 & 8.230 \\
\hline 2nd Week & 40 & & 8.377 \\
\hline 3rd Week & 40 & & 8.385 \\
\hline Sig. & & .715 & .075 \\
\hline
\end{tabular}

Means for groups in homogeneous subsets are displayed.

Based on observed means.

The error term is Mean Square(Error) $=.134$.

a. Uses Harmonic Mean Sample Size $=40.000$.

b. The group sizes are unequal. The harmonic mean of the group sizes is used. Type I error levels are not guaranteed.

c. Alpha $=.05$.

Table 5 shows a continuous increase in the standard length and the bodies expansion of the fish preserved continuously in both solutions. A twoweek preservation period (in formalin) gave the highest reading of the standard length measurement. The fish bodies began to shrink again at the end of the experiment; whereas the fish bodies preserved in alcohol reached the highest reading of the standard length at the third week. However; they shrank again at the end of the experiment for both bodies preserved in the two solutions with different compositions. The difference in the chemical composition of these two solutions may be a major impact on the standard length of the fish bodies preserved in them. This is opposite to what was stated by (Jawad, 2003) in his study; the increases in standard length were greater for the bodies of fish preserved in alcohol $70 \%$ than those fish preserved in formalin $5 \%$. The cause may be the difference 
between the water used to dilute the solutions or maybe the different storage temperatures; besides, the difference in formalin concentration in the two experiments, which gave different durations for the contraction and expansion for the fish bodies in the two experiments. The difference between the studied species in both studies may be also another cause. The bodies may differ according to the type in the speed of response to the preservation solutions and thus the speed of contraction and expansion may be affected.

Some previous studies have shown that standard body lengths are lower when fixed in formalin $10 \%$ and then preserved in $70 \%$ alcohol for a long time (Shields and Carlson, 1996) and (Greszkiewicz and Fey, 2018). However, in this study the models were preserved, each separately in formalin $10 \%$ and alcohol $70 \%$ for a month only, and completely isolated, (Hossaini et al.,2016) mentioned that after an initial evaluation on morphological characters, Samples were fixed and preserved in $96 \%$ alcohol for 3 months. Results indicated that shrinkage was common in all the specimens and changes in body color were clearly distinguishable compared with fresh fish such a way that the body and fin colors were opaque, while color pattern was detectable, although the intensity was reduced

Table 6. Head Length

\begin{tabular}{|c|c|c|c|}
\hline \multirow{2}{*}{ Time } & \multirow{2}{*}{$\mathbf{N}$} & \multicolumn{2}{|c|}{ Subset } \\
\cline { 3 - 4 } & & 1 & 2 \\
\hline 4th Week & 40 & 1.980 & \\
\hline 1st Week & 40 & 2.000 & 2.000 \\
\hline 3rd Week & 40 & 2.032 & 2.032 \\
\hline 2nd Week & 40 & & 2.068 \\
\hline Sig. & & 0.132 & 0.052 \\
\hline
\end{tabular}

Means for groups in homogeneous subsets are displayed.

Based on observed means.

The error term is Mean Square(Error) $=.021$.

a. Uses Harmonic Mean Sample Size $=40.000$.

b. The group sizes are unequal. The harmonic mean of the group sizes is used. Type I error levels are not guaranteed.

c. Alpha $=.05$.

On the other hand, the measurement of the head had some changes as well. Table (6) shows the speed of expansion of the heads of fish preserved in formalin $10 \%$. The peak of expansion was in the second week of preservation; then, it quickly shrank in the third. After these rapid variations in the fourth week. Unlike the measurement of the head length of fish preserved in alcohol $70 \%$, we notice from table 6 that it was slow to stabilize at the second week of the experiment and the measurements of head length fluctuated rapidly to give the highest reading at the third week to stabilize in the fourth week. The measurement of the head length in both solutions in the second week specifically gave the first change. These results were identical to what was stated by (Jawad, 2003), as a constant contraction was recorded in the head length of the fish preserved in $5 \%$ of distilled water and formalin; however, there was a sudden shrinkage, although there was a slight fluctuation of water $10 \%$ of the fish in the second week studied in these two experiments.

The weight change characteristic of fish preserved in two preservative solutions, formalin $10 \%$ and alcohol $70 \%$, were studied. Table 7 shows us that fish shrank sharply in both solutions to record in the second week the highest reading of body shrinkage and weight loss; the average weight of fish preserved in alcohol $70 \%$ was $26.5 \mathrm{gm}$, whereas the average weight of fish preserved in formalin $10 \%$ was $20.8 \mathrm{gm}$, maintaining a slight increase in the third week, as the bodyweight of fish preserved in alcohol $70 \%$ became $26.7 \mathrm{gm}$ and in formalin $10 \%$ became $20.8 \mathrm{gm}$. Then, in the fourth week, it maintained its initial weights before the experiment. It is noticed that despite the rapid contraction and expansion in the bodies of fish preserved in alcohol $70 \%$ and the slow contraction and expansion in formalin $10 \%$, the periods of expansion and weight gain were equal in the second week. There was a slight shrinkage that continued to the third week; the weight, of both bodies preserved in these two solutions, regained its normal level at the beginning of the experiment in the fourth week. (Shields and Carlson, 1996) explained that after 106 days of their experiment there was a significant increase with a high moral value for salmon weight when preserved in formalin $5 \%$ distilled water, while there were no significant changes in body weight of fish preserved in alcohol $70 \%$ distilled water for the same experiment. (Shields and Carlson, 1996) and (Ajah and Nunoo, 2003) confirm that most fish bodies preserved in formalin at a concentration of $10 \%$ gain significant weight after a period of preservation.

Sotola et al (2019) argues that most of the biometrics of fish bodies fixed in formalin $10 \%$ and then preserved in $70 \%$ alcohol show clear changes at the fourth week of preservation. This period is 
consistent with the duration of the present study, which also lasted for one month. The bodies shapes undergo significant and clear changes when preserved in solutions of formalin $10 \%$ and alcohol $70 \%$ (Berbel et al, 2013) and (Martinez et al, 2013). The biometrics of fish bodies preserved for a period of more than ten years may change to be of useless value, due to the long shelf life (Larochelle et al, 2016).

Table 7. Weight

\begin{tabular}{|c|c|c|c|}
\hline \multirow{2}{*}{ Time } & \multirow{2}{*}{$\mathbf{N}$} & \multicolumn{2}{|c|}{ Subset } \\
\cline { 3 - 4 } & & 1 & 2 \\
\hline 2nd Week & 40 & 10.875 & \\
\hline 3rd Week & 40 & 11.450 & \\
\hline 1st Week & 40 & & 12.450 \\
\hline 4th Week & 40 & & 12.450 \\
\hline Sig. & & .091 & 1.000 \\
\hline
\end{tabular}

Means for groups in homogeneous subsets are displayed.

Based on observed means.

The error term is Mean Square(Error) $=2.289$.

a. Uses Harmonic Mean Sample Size $=40.000$.

b. The group sizes are unequal. The harmonic mean of the group sizes is used. Type I error levels are not guaranteed.

c. Alpha $=.05$.

There was no curvature in the fish body preserved, for a preservation period that lasted four weeks, in both solutions formalin $10 \%$ and alcohol $70 \%$. It was possible that the short preservation period, in the present study, did not allow the fish bodies to curve due to the shrinkage that occurs when preserved for a period of time longer than the preservation period in this study. (Valentin et al, 2008) explains that the curvature of fish bodies preserved in formalin and alcohol occurs when the preservation period is long, which gives false and difficult readings of the biometrics of fish bodies preserved in these solutions.

\section{Conclusions}

We conclude here that the difference in the response of fish bodies to the states of contraction, expansion, and weight gain, when preserved in alcohol, is due to the difference between the different environments of the studied species, whether they are saltwater fish or freshwater fish. Besides; there is a difference between species according to their genetic makeup, which is influenced by the environment in which these species are found. The difference in the composition of fish bodies varies according to fish types, having white muscles or red muscles, which lead to apparent differences in the contraction and expansion of fish bodies Moreover; the size of the body also affects the fish preserved in their response to changes when preserved in formalin and alcohol. The environment is one of the important factors in the formation and the nature of fish types; especially since genetic factors are affected by the environment. Hence, there are differences in the changes occurring on fish bodies, such as the biometrics of some studied characteristics of fish bodies when preserved in solutions preservation or freeze.

\section{Conflict of interests}

The author whose name is listed below certifies that he has no affiliations with or involvement in any organization or entity with any financial interest, or non-financial interest (such as personal or professional relationships, affiliations, knowledge, or beliefs) in the subject matter or materials discussed in this manuscript.

\section{Acknowledgments}

Many thanks to Dr. Ali Arif from the college of Languages, Department of English language to review and evaluate the English language of this manuscript.

\section{References}

Al-Daham,N.K. 1984. Fishes of Iraq and the Arab gulf. Vol.3,Perciformes (Mugiloidei) to Tetraodontiformes. Basrah: Basrah University Press (in Arabic).

Al-Hassan L.A.J. and Abdullah, J.N. 1992. The effect of formalin and some body proportions of Barbusluteus. Pakistan Journal of Zoology 24: 353354.

Al-Hassan, L.A.J. and Shawafi, N.A. 1997. The effect of preservatives and freezing on the morphological characters of Rastrelligerkanagurta(Pisces: Scombridae). Journal of Animal Morphology and Physiology 44(1): 1720.

Al-Hassan L.A.J., Bujawari, J.A. and El-Silini, O.A. 1999. Additional report on the effect of 
preservatives and freezing on morphological characters of four sparid fish species collected from Benghazi, Libya. Journal of Animal Morphology and Physiology 46(1-2): 57-62.

Al-Hassan, L. A., Bujawari, J. A., and El-Silini, O. A. 2000. The effect of some preservatives and freezing on certain body dimensions of two species of the family Mullidae collected from Benghazi waters, Libya. Acta Ichthyologica et Piscatoria, 2(30):127-136.

Ajah P.O., and Nunoo, F.K. 2003.The effects of four preservation methods on length, weight and condition factor ofthe clupeid Sardinella aurita Val. 1847. Journal of Applied Ichthyology. 19(6):391393.

Anyanwu, A.O.1993. Protein electrophoresis, Meristic and Morphometric parameters in the Racial studies of commercial fish species of the Nigerian Coast. Ph.D. Thesis, University of lbadan, Nigeria.

Arrington, D.A., and Winemiller, K.O. 2002. Preservation effects on stable isotope analysis of fish muscle. Transactionsof the American Fisheries Society. 131(2):337-342.

Banha, F., Verissimo, A., Ribeiro, F., Anastacio, P. M. 2017. Forensic reconstruction of Ictalurus punctatus invasion routes using on-line fishermen records. Knowledge and Management of Aquatic Ecosystems, 56, 418.

Berbel-Filho, W.M., Jacobina, U.P.,and Martinez, P.A. 2013. Preservation effects in geometric morphometric approaches: freezing and alcohol in a freshwater fish. Ichthyological Research. 60(3):268-271.

Billy A. J. 1982. The effect of formalin and isopropyl alcohol on length and weight measurements of Sarotherodon mossambicusTrewaves. Journal of Fish Biology 21(1):107-112.

Burgner, R. L. 1962. Studies of red salmon smolts from the Wood River Lakes, Alaska. Studies of Alaska red salmon. University of Washington Press, Seattle, 247-314.

Cultter,R.I., and L.E. Whitesel. 1956. Collection and interpretation of sockeye and salmon scales. Bulletin of the international Pacific salmon fisheries commission 9.
Dallinger, R.; Prosi, F. ;Segner, H. and Black,H. 1987.Contamination Food and Up take of Heavy Metal by Rainbow Trout (Salmogairdneri) Afield Study. Oecologia, 73(1): 91-98.

Engel, S. 1974. Effects of formalin and freezing on length, weight and condition factor of cisco, and yellow perch, Percaflavescens. Transaction of the American Fisheries Society 103(1): 136-138.

Florin A. B, Lingman A. 2008. Shrinkage of flounder Platichthys flesus (L.) and turbo Psetta maxima (L.) following freezing.J Fish Biol 72(3):731-736.

Greszkiewicz, M., and Fey, D. P. 2018. Effect of preservation in formalin and alcohol on the growth rate estimate oflarval northern pike. North American Journal of Fisheries Management. 38(3):601-605.

Haubrock, P. J., Balzani, P., Johović, I., Inghilesi, A. F., and Tricarico, E. 2018. The effects of two different preservation methods on morphological characteristics of the Alien channel catfish Ictalurus punctatus, Croatian journal of fisheries ,76:80-84.

Hossaini, S.A., Vajargah, M.F., Sattari, M. 2016. The effect of preservation in alcohol on the morphological characters of the Zagros tooth-carp, Aphanius vladykovi Coad. Journal of Environmental Treatment Techniques, 4, 4, 118120.

Jassem, M. Salman, Fekret,M. Hussan and Mason M. 2007. Concentrations of Nine heavy elements in the fish muscles HamriBarbusgrypus and ShillukAspiusvoraxHeckel and Silver carp Hypophthalmicthyesmolotrix Collected from the Euphrates River,Environmental Research and Sustainable Development Magazine,Vol. 10: 5-20.

Jawad, L. A. 2003.The effect of formalin, alcohol and freezing on some body proportions of Alepes djeddaba (Pisces: Carangidae) collected from the Red Sea coast of Yemen, Revista de Biología Marina y Oceanografía 38 (2): 77 - 80.

Kelvin, K. P. Lim and, N. Sivasothi. 1994. A guide to methods of preserving animal specimens in liquid preservatives. Originally prepared for the Zoo Hons '94 field course.

Khalaf,K.T. 1961.The marine and fresh water fishes of Iraq. Baghdad. 
Larochelle, C. R., Pickens, F. A. T., Burns, M. D., and Sidlauskas, B. L. 2016. Long-term isopropanol storage does not alter fish morphometrics104 (2): 411-420.

Leslie, J. K., and J. E. Moore. 1986. Changes in lengths of fixed and preserved young freshwater fish. Canadian Journal of Fisheries and Aquatic Sciences, 43(5): 1079-1081.

Lux, F.E. 1960. Length shrinkage of yellowtail flounder, Limanda ferruginea between live and land condition. Transaction of the American Fisheries Society 89(4): 373-374.

Mahdi, N. 1962. Fishes of Iraq .Ministry of Education, Baghdad, pp 66.

Martinez, P. A., Berbel-Filho, W. M., and Jacobina, U. P. 2013. Is formalin fixation and ethanol preservation able to influencein geometric morphometric analysis? Fishes as a case study. Zoomorphology.132(1):87-93.

Misra, K.S. 1947. On a second collection of fish from Iraq. Rec. Indian Mus. Calctta. 45:115-127.

Nelson, J.S. 2006. Fishes of the world. 4th ed. NewYork: J Wiley, 601 pp.

Olaifa, F. E., Olaifa, A. K., Adelaja, A. A.,and Owolabi, A. G. 2004. Heavy Metal Concentration of Clarias gariepinus from A lake and Fish from in Ibadan, Nigeria. African Journal of Biomedical Research,Vol.7(3): 145-148.

Parker, R.P. 1963. Effects of formalin on length and weight of fishes. Journal of the Fisheries Board of Canada 20(6): 1441-1455.

Razzaq, W., F. Iqbal, Masood Z. and Khawar. M. 2015. Study of some Morphometric and Meristic
Characters of a Parassi mullet, Mugilincilis (Mugilidae: Mugiliformes) from the Indus River at Sukkur District of province Sindh, Pakistan,Biological forum an International Journal 7(1): 767-772.

Sayers, R.E. 1987. Effects of freezing in and out of water on length and weight of Lake Michigan Bloaters, Coregonushoyi. North American Journal of Fisheries Management 7(2): 299-301.

Shields and Carlson S.R. 1996. Effects of formalin and alcohol preservation on lengths and weights of juvenile sockeye salmon. Alaska Fishery Research Bulletin.; 3(2):81-93.

Sotola,V. A., Craig, C. A., Pfaff, P. J., Maikoetter, I. J. D., Martin., N. H., and Bonner,T. H. 2019. Effect of preservation on fish morphology over time: Implications for morphological studies, Plos one, 14(3).

https://doi.org/10.1371/journal.pone.0213915

Stobo, W.T. 1972. Effects of formalin on the length and weight of yellow perch, Perca flavescens. Transaction of the American Fisheries Society 101(2): 362-364.

Thomson, J. M. 1997. The Mugilidae of the world. Mem. Queensl. Mus., 41: 457-562.

Valentin, A.E., Penin X., Chanut, J.P., Se'vigny, J.M., Rohlf, F. J. 2008. Arching effect on fish body shape in geometric morphometric studies. Journal of Fish Biology 73:623-638.

Wilke, H. J., Krischak, S., and Claes L.E. 1996. Formalin fixation strongly influences biomechanical properties of the spine. Journal of biomechanics. 29 (12):1629-31. 